\title{
Phosphorus fertilization, soil stratification, and potential water quality impacts
}

\author{
D.R. Smith, C. Huang, and R.L. Haney
}

\begin{abstract}
Water quality experts have suggested that no-till induces phosphorus (P) stratification, which may exacerbate soluble P (SP) runoff from agricultural fields, contributing to eutrophication. Conservationists have been concerned about increased SP loading to Lake Erie, which has been partially blamed on adoption of no-till and the concomitant P stratification of no-till soils. This study was conducted to provide better insight into the potential link between $\mathrm{P}$ stratification from no-till soils and $\mathrm{P}$ losses via runoff with the objective of exploring $\mathrm{P}$ fertilization strategies on $\mathrm{P}$ stratification and $\mathrm{P}$ runoff from a corn (Zea mays L.)-soybean (Glycine $\max$ L.) rotation. Plots were established with nine treatments, including unfertilized, diammonium phosphate (DAP) applications, monoammonium phosphate (MAP) applications, surface applied, injecting fertilizer or tilling fertilizer in, and the use of cover crops. Fertilizer applications were made at $24.4 \mathrm{~kg} \mathrm{P} \mathrm{ha}^{-1}\left(21.8 \mathrm{lb} \mathrm{P} \mathrm{ac}^{-1}\right)$ every other year or at $9.6 \mathrm{~kg} \mathrm{P} \mathrm{ha}^{-1}\left(8.7 \mathrm{lb} \mathrm{P} \mathrm{ac}^{-1}\right)$ every year. Disking, which was intended to minimize $\mathrm{P}$ stratification, resulted in the greatest stratification, with significantly higher water SP and Mehlich $3 \mathrm{P}$ in the 0 to $5 \mathrm{~cm}$ (0 to 2 in) soil layer compared to the other treatments. There were no differences in SP or total $\mathrm{P}(\mathrm{TP})$ runoff from rainfall simulations between fertilizer source (MAP versus DAP) or fertilizer rate (annual versus biennial). The highest SP concentrations observed were from DAP applied to cover crops at the high application rate $(24.4$ $\mathrm{kg} \mathrm{P} \mathrm{ha}{ }^{-1}$ applied every other year). This may suggest cover crops are not the ideal practice to decrease SP losses from agricultural fields. Incorporation of fertilizer reduced SP but increased erosion and could potentially increase TP loss. Injecting liquid fertilizer (polyphosphate [Poly]) at the time of planting resulted in lower SP and TP loads than surface applied fertilizers. We encourage other researchers to confirm these results at the field-to-watershed scale to ensure there are not unintended consequences of adopting this fertilization strategy. Further, fertilizer dealers, crop consultants, and farmers should be encouraged to consider liquid fertilizer applications as one option to minimize P losses.
\end{abstract}

Key words: cover crops—-fertilizer management - phosphorus stratification—runoff

In the 1990s, Lake Erie was held up as a success story for the Clean Water Act, as the total phosphorus (TP) load had declined below an 11,000 Mg (12,100 tn) loading target due in large part to $P$ reductions from point sources as well as from nonpoint sources through improved management of agricultural lands (Richards and Baker 1993). However, in recent years $\mathrm{P}$ losses from agricultural fields in the Western Lake Erie Basin (WLEB) have been identified as a primary contributor to resurgent harmful and nuisance algal blooms (HNABs) in Lake Erie (Chaffin et al. 2011). While there has not been any significant change in TP loading since the pared to tilled fields (Gaynor and Findlay 1995; Zhao et al. 2001; Smith et al. 2015a). Practices such as residue management (i.e., no-till and reduced tillage), buffer strips, and cover crops have been suggested to reduce $\mathrm{P}$ losses to water. However, analysis of these practices have indicated that they are effective for reducing TP but not SP (Sharpley et al. 2000). Cade-Menun et al. (2015) observed stratification of orthophosphate and phytate in no-till and tilled soils fertilized with poultry litter. The mechanism for P stratification is likely two-fold: (1) the application of largely immobile P fertilizers on the soil surface that are not incorporated, and (2) surface deposition of $\mathrm{P}$ that has been taken up from lower soil profiles by crop residue without incorporation (Scheiner and Lavado 1998). Studies conducted in agricultural fields in the WLEB have shown that no-till, as well as other conservation practices intended to reduce erosion (e.g., grassed waterways), have been shown to increase SP loads (Smith et al. 2015a). In the WLEB, P stratification resulting from no-till and other conservation tillage practices is prevalent, and has been identified as a potential contributor to the return of HNABs in Lake Erie (Sharpley et al. 2012; Smith et al. 2015c).

Between 1975 and 1995, no-till corn (Zea mays L.) and soybean (Glycine max L.) in the WLEB increased from $0 \%$ to $50 \%$ of the WLEB, and the extent of continuous no-till has essentially remained steady since 1995 (Richards et al. 2002). Fertilizer P use decreased about $20 \%$ and manure $\mathrm{P}$ applications decreased about $25 \%$ during this same period (Richards et al. 2002). Surplus P, when calculating a mass balance in 1971, was roughly $12 \mathrm{~kg} \mathrm{P} \mathrm{ha}^{-1}$ (11 $\mathrm{lb} \mathrm{P} \mathrm{ac} \mathrm{P}^{-1}$ ), which decreased to $4.4 \mathrm{~kg} \mathrm{P} \mathrm{ha}{ }^{-1}\left(3.9 \mathrm{lb} \mathrm{P} \mathrm{ac}^{-1}\right)$ by 1995 (Baker and Richards 2002).

Fertilizer recommendations were developed based on studies conducted at a time when wholesale tillage was occurring. Therefore, one would expect $\mathrm{P}$ fertilizers to be incorporated into the plow-layer during

tion of no-till in this watershed. Great efforts were made to increase adoption of conservation tillage, preferably no-till, to reduce sediment losses to water bodies and thereby induce a concomitant decrease in P loading. Some water quality experts have suggested that increases in SP loading that occurred with simultaneous peak adoption of no-till indicates a causal link between these two events (Smith et al. 2015c).

Indeed, no-till has been shown through many studies to increase SP loading com-
Douglas $\mathbf{R}$. Smith is a research soil scientist for the USDA Agricultural Research Service (ARS) Grassland, Soil and Water Research Laboratory in Temple, Texas. Chi-hua Huang is a research soil scientist for the USDA ARS National Soil Erosion Research Laboratory in West Lafayette, Indiana. Rick L. Haney is a research soil scientist for the USDA ARS Grassland, Soil and Water Research Laboratory in Temple, Texas. 
tillage. Indeed, soil test fertilizer recommendations are based on the "available" $\mathrm{P}$ in the plow-layer (i.e., 0 to $20 \mathrm{~cm}$ [8 in] depth; Vitosh et al. 1995). Currently, however, P fertilizers are generally applied via surface broadcast applications and very little consideration is given to incorporating $\mathrm{P}$ into the soil profile. Incorporation has long been known to safeguard applied P from losses via surface runoff (Sharpley et al. 1991; Smith et al. 1991). The risk of $P$ loss from surface runoff processes when manures are applied has been recognized (Mamo et al. 2005), leading to recommendations to incorporate manures into the soil (Sharpley 2003). Despite commercial fertilizers containing greater concentrations of soluble $\mathrm{P}$ than manures, this recommendation is not generally recognized for commercial $\mathrm{P}$ fertilizer applications. Early work on the impact of conservation tillage in agricultural soils led to the conclusion that $\mathrm{P}$ stratification may develop (Cruse et al. 1983). No-till induced $\mathrm{P}$ stratification in cotton (Gossypium hirsutum) has resulted in a recommendation to update fertility recommendations for no-till soils (Howard et al. 1999). Others have also concluded that in highly $\mathrm{P}$ stratified soils, $\mathrm{P}$ should be subsurface applied (Robbins and Voss 1991; Schwab et al. 2006).

It is therefore important for conservationists and agronomists to understand the potential role of no-till induced $\mathrm{P}$ stratification on SP losses. Further, if these fields do pose a potential risk, there is currently no fertility management or conservation practice guidance to alleviate these potential risks. Some agronomists and a few conservationists in the WLEB have recommended targeted tillage to reduce the potential impact of $\mathrm{P}$ stratification in no-tilled soils to alleviate the potential SP losses (Frankenberger 2012). Other conservationists have promoted cover crops as the most likely practice to alleviate the SP loading to Lake Erie, while the USDA Natural Resources Conservation Service (NRCS) has invested heavily in cost-share cover crops in the WLEB (Maxwell 2014). Further, there is little guidance to farmers as to the forms of $\mathrm{P}$ application or the timing of $\mathrm{P}$ applications within the crop rotation that may reduce $\mathrm{P}$ losses.

Potential practices to reduce $\mathrm{P}$ loss from agricultural fields may include changing the rate of fertilizer application, using other $\mathrm{P}$ sources, incorporating $\mathrm{P}$ fertilizers, or using cover crops. The objectives of this study were to assess the role of fertilizer management on $\mathrm{P}$ stratification in soils and the resulting impact on the potential for P loss via surface runoff processes. Insofar as possible, the concepts of fertilizer source, application timing, placement, and use of cover crops were examined independently, while fertilizer rates (i.e., applying smaller amounts every year as opposed to applying enough for two crops every other year) were used in cooperation with other treatments. In addition to $\mathrm{P}$ runoff, ammonium-nitrogen $\left(\mathrm{NH}_{4}-\right.$ $\mathrm{N})$, nitrate- $\mathrm{N}\left(\mathrm{NO}_{3}-\mathrm{N}\right)$, total Kjehldahl $\mathrm{N}$ (TKN), and sediment losses in runoff were analyzed to examine any potential water quality tradeoffs resulting from the treatments used in this study. This is the first study to combine these treatments to assess the influence these agronomic practices have on soil $\mathrm{P}$ stratification and runoff water quality.

\section{Materials and Methods}

Plots for this study were established in 2012 at the Throckmorton Purdue Agricultural Center near West Lafayette, Indiana. Plots measured $9.1 \times 18.2 \mathrm{~m}(30 \times 60 \mathrm{ft})$, and treatments were applied in a randomized complete block design with four replications of each treatment. Prior to this study, the area where the plots were located was a bulk production area for corn and soybean in rotation. Grassed alleys were used to divide main plot areas.

The nine treatments used in this study are listed in table 1. Briefly, treatments included three commercial fertilizer $\mathrm{P}$ sources, two application rates/timings $\left(9.6 \mathrm{~kg} \mathrm{ha}^{-1}[8.7 \mathrm{lb}\right.$ $\mathrm{ac}^{-1}$ ] applied every year versus $24.4 \mathrm{~kg} \mathrm{ha}^{-1}$ [21.8 $\left.\mathrm{lb} \mathrm{ac}^{-1}\right]$ applied every other year), and three application methods. Disking resulted in soil disturbance to roughly $10 \mathrm{~cm}$ (4 in) deep. Knifed in fertilizer applications were made $5 \mathrm{~cm}$ below and $5 \mathrm{~cm}$ to the side $(2$ $\times 2$ in) of the seed row. Nitrogen fertilizers were applied to all plots, including the control, which received no $\mathrm{P}$ fertilizer, at a rate of 202 $\mathrm{kg} \mathrm{N} \mathrm{ha} a^{-1}\left(180 \mathrm{lb} \mathrm{N} \mathrm{ac}^{-1}\right)$. Phosphorus applications and incorporation/tillage (if any) were conducted 24 hours prior to soil sampling.

One subplot with a $3 \%$ to $6 \%$ slope was placed in each main plot to perform rainfall simulations. Rainfall simulation subplots (2 $\times 1 \mathrm{~m}[6.6 \times 3.3 \mathrm{ft}])$ were used each year and marked with GPS coordinates. Subplots for rainfall simulations were hydrologically isolated from the surrounding soil using 15 $\mathrm{cm}$ (6 in) wide galvanized edging. The edg- ing was installed $10 \mathrm{~cm}$ (4 in) deep into the soil immediately after fertilizer treatments were applied. Composited soil samples (six to eight cores) were collected from the area immediately around the subplots at 0 to $5 \mathrm{~cm}$ ( 0 to 2 in) and 5 to $20 \mathrm{~cm}$ ( 2 to 8 in) depths prior to the initiation of rainfall simulations. Soils were dried, ground, and sieved to pass a \#10 sieve. Soils were extracted with deionized water (Self-Davis and Moore 2000), Mehlich 3 (Mehlich 1984), and H3A (Haney Soil Test; Haney et al.2010), followed by analysis of extracts with ICP-OES.The P sorption ratio for soils was calculated from Mehlich 3 and $\mathrm{H} 3 \mathrm{~A}$ extractions as the molar ration of $\mathrm{P}$ to aluminum (Al) plus iron $(\mathrm{Fe})$ (Maguire and Sims 2002). Phosphorus stratification was calculated from each of the three extractions as the $\mathrm{P}$ concentration in the surface soil layer divided by the $\mathrm{P}$ concentration in the 5 to 20 $\mathrm{cm}$ (2 to 8 in) soil layer.

Deionized water was used for rainfall simulations, which occurred at a rate of 70 $\mathrm{mm} \mathrm{h}^{-1}\left(2.8\right.$ in $\left.\mathrm{hr}^{-1}\right)$ based on National $\mathrm{P}$ Runoff Project (NPRP; SERA-17 2015), with rainfall initiation occurring approximately 24 hours after fertilizer applications were made. All rainfall simulations occurred within a one week period in May, prior to planting the crop. Simulated rainfall was applied on each plot for a period sufficient to produce 30 minutes of continuous runoff. Discrete runoff samples were collected every five minutes during the rainfall simulations. In brief, runoff water was collected in a 500 $\mathrm{mL}(1.1 \mathrm{pt})$ bottle for one to two minutes, with the water volume and collection period recorded to subsequently determine the flow rate for each period and sample. A $60 \mathrm{~mL}(2$ $\mathrm{Oz}$ ) aliquot of each discrete runoff sample was used in digestions for TKN and TP. A 20 $\mathrm{mL}(0.68 \mathrm{oz})$ aliquot from each discrete runoff sample was filtered $(0.45 \mu \mathrm{m} ; 0.000018$ in) and acidified to $\mathrm{pH}<2$ for analysis of soluble nutrients. Both aliquots were frozen until analysis could be performed.

Soluble $\mathrm{P}, \mathrm{NO}_{3}-\mathrm{N}$, and $\mathrm{NH}_{4}-\mathrm{N}$ were analyzed using US Environmental Protection Agency (USEPA) methods 365.2, 353.1, and 350.1, respectively (USEPA 1983). USEPA methods 351.2 and 365.4 were used for TKN and TP after mercuric sulfate digestion of an unfiltered sample. All analyses were performed colorimetrically with a Konelab Aqua 20 (EST Analytical, Medina, Ohio).

Nutrient loads used for statistical analysis were the sum of both years. Nutrient loads 


\section{Table 1}

Fertilizer source, rate, timing, and placement for treatments used in this study.

\begin{tabular}{|c|c|c|c|c|}
\hline Treatment & Source & Rate (kg ha-1) & Time & Placement \\
\hline 1 & Unfertilized & 0.0 & & \\
\hline 2 & DAP & 9.6 & Annually & Surface \\
\hline 3 & DAP & 24.4 & Every other year & Surface \\
\hline 4 & MAP & 9.6 & Annually & Surface \\
\hline 5 & MAP & 24.4 & Every other year & Surface \\
\hline 6 & Poly & 9.6 & Annually & Knifed in \\
\hline 7 & DAP & 24.4 & Every other year & Disked in \\
\hline 8 & DAP + cover crop & 9.6 & Annually & Surface \\
\hline 9 & DAP + cover crop & 24.4 & Every other year & Surface \\
\hline
\end{tabular}

Notes: $\mathrm{DAP}=$ diammonium phosphate. $\mathrm{MAP}=$ monoammonium phosphate. Poly = polyphosphate.

transported from the rainfall simulations were calculated as the concentration of the discrete samples collected multiplied by the estimated runoff volume for each discrete period. The flow weighted mean concentrations (FWMC) were calculated as the sum of the mass lost from each plot divided by the sum of the volume of runoff water from both rainfall simulations that occurred in 2013 and 2014. Data presented here represent water quality from rainfall simulations for the entire crop rotation. The decision was made to combine data from the 2013 soybean year with the data from the 2014 corn year. Thus, the data are presented for the rotation, not for individual crops. As the fertilizer treatments are intended to fertilize for both crops in the corn-soybean rotation, nutrient losses from the complete rotation were deemed more important than individual years.

Data were statistically analyzed using JMP version 10.0.0 (SAS Institute, Cary, North Carolina). Nutrient runoff data (loads and concentrations) were lognormally distributed and were transformed accordingly prior to statistical analysis and back-transformed for presentation here. Analysis of variance (ANOVA) was used for statistical analysis and Student's $t$-test was used to compare means when ANOVA indicated a significant treatment effect. In addition to the mean separation, contrasts were made among treatments to determine the treatment main effects. For all contrast comparisons except rate, DAP applied to the surface at 9.6 and $24.4 \mathrm{~kg} \mathrm{P} \mathrm{ha}^{-1}$ (8.7 and $21.8 \mathrm{lb} \mathrm{P} \mathrm{ac}^{-1}$, respectively) were used as the base comparison. For the $\mathrm{P}$ source contrast comparisons, the DAP treatments were compared to the MAP treatments. The DAP treatments were compared to the polyphosphate (Poly) and DAP disked treatments for a placement contrast comparison. The cover crop contrast compared the
DAP surface applied to the DAP applied to cover crops. MAP and DAP applied at 24.4 $\mathrm{kg} \mathrm{P} \mathrm{ha}{ }^{-1}$ were compared to MAP and DAP applied at $9.6 \mathrm{~kg} \mathrm{P} \mathrm{ha}^{-1}$ for the rate contrast.

\section{Results and Discussion}

Soil Test. The DAP treatment that was disked resulted in the greatest WSP, M3P, and $\mathrm{H} 3 \mathrm{~A} P$ at the 0 to $5 \mathrm{~cm}$ (0 to 2 in) layer (table 2). WSP in the surface layer was significantly higher from the Poly treatment that was knifed in compared to the surface applied MAP that was applied at the same rate. The contrasts were significant for placement, with greater WSP, M3P, and H3A P in the surface layer for incorporated fertilizers. Additionally, the contrast comparison showed significantly greater H3A P sorption ratio (PSR) for the incorporated fertilizers compared to surface applications in the 0 to $5 \mathrm{~cm}$ soil profile.

In the 5 to $20 \mathrm{~cm}$ (2 to 8 in) layer, WSP for the low rate of DAP applied to a cover crop (1.55 mg P kg-1 [1.55 ppm]) was significantly greater than all other treatments except the knifed in Poly treatment (1.35 $\mathrm{mg} \mathrm{kg}^{-1}$; table 2). There was no significant difference for any of the contrast comparisons tested for the primary treatment main effects (source, rate, placement, or cover crop). H3A P at the 5 to $20 \mathrm{~cm}$ soil layer was greater for the cover crop treatments than the surface applied DAP treatments.

Phosphorus stratification for WSP was significantly greater in the disked DAP treatment than the other treatments (table 2 ). This is a critical result for conservation practitioners, as tillage has been identified in the region as a practice to target critical acres with severe $\mathrm{P}$ stratification issues. Light tillage, such as the disking practices represented in this study, may exacerbate the P stratification problem. More intense inversion tillage practices (e.g., moldboard plow) may hypothetically alleviate $\mathrm{P}$ stratification; however, intensive management would be required to protect the soil immediately after tillage.

There was a trend $(p=0.11)$ of slightly more stratification in the high $\mathrm{P}$ rate (2.62) compared to the low $\mathrm{P}$ rate $(1.75$; table 2$)$. WSP stratification was significantly greater for treatments in which $\mathrm{P}$ was placed in the subsurface compared to surface applied DAP treatments. Similarly, H3A P stratification tended to be greater $(p=0.058)$ from the subsurface applied $\mathrm{P}$ compared to surface applied P.

Stratification of $\mathrm{P}$ on a nearby farm was observed for both the long-term native no-till condition, as well as following vertical tillage (Smith and Warnamuende-Pappas 2015). Costa et al. (2010) observed stratification of $\mathrm{P}$ near the surface in long-term (1990 to 2007) plots in which tillage and no-till were primary treatments. Surface ( 0 to $5 \mathrm{~cm}$ [0 to 2 in]) $\mathrm{P}$ concentrations were markedly greater in no-till soils with broadcast $\mathrm{P}$ applications than tilled soils with the same fertilizer treatment during the first 10 years of their study (increase from about $20 \mathrm{mg} \mathrm{kg}^{-1}$ [20 ppm] to about $28 \mathrm{mg} \mathrm{kg}^{-1}$ [28 ppm]; Costa et al. 2010). Further, after 17 years in no-till soils with banded $\mathrm{P}$ applications, elevated $\mathrm{P}$ concentrations were observed in the 0 to $5 \mathrm{~cm}$ (0 to 2 in) and the 5 to $10 \mathrm{~cm}$ ( 2 to 4 in) soil depths (Costa et al. 2010). In a study of tilling no-till soils in Nebraska, the only treatment that was shown to significantly decrease surface soil $\mathrm{P}$ concentrations and minimize $\mathrm{P}$ stratification was the moldboard plow (Garcia et al. 2007). A corn-soybean rotation that was tilled resulted in lower P concentrations in the 0 to $5 \mathrm{~cm}$ soil depth than the no-till treatment, whereas there were greater $\mathrm{P}$ concentrations in the 5 to $10 \mathrm{~cm}$ soil depth from the tilled soil than the no-till (Houx et al. 2011). In a four-year study of banding $\mathrm{P}$ fertilizers at 13 to $18 \mathrm{~cm}$ (5 to 7 in) below the surface, $\mathrm{P}$ stratification occurred in tilled and no-tilled soils near the surface (Mallarino and Borges 2006). Phosphorus was stratified in all treatments in this study (table 2), including the unfertilized control plots, independent of the extractant used. The greatest $\mathrm{P}$ concentrations were observed in the surface layer, and thus the greatest stratification occurred in the disked plots. It is possible this occurred because the tillage operation was not inversion tillage, such as what was used in the studies that have min- 
Table 2

Soil phosphorus $(P)$ response to fertilization treatments used to study the impact of fertilizer source, placement, rate, and the use of cover crops as potential methods to minimize $P$ loss from corn-soybean rotation.

\begin{tabular}{|c|c|c|c|c|c|c|c|c|c|c|c|c|c|}
\hline \multirow[b]{2}{*}{ Source } & \multirow[b]{2}{*}{ Rate } & \multirow[b]{2}{*}{ Placement } & \multicolumn{5}{|l|}{0 to $5 \mathrm{~cm}$} & \multicolumn{3}{|l|}{5 to $20 \mathrm{~cm}$} & \multicolumn{3}{|c|}{ P stratification } \\
\hline & & & $\begin{array}{l}\text { WSP } \\
\left(\mathrm{mg} \mathrm{P} \mathrm{kg}^{-1}\right)\end{array}$ & $\begin{array}{l}\text { M3P } \\
\left(\mathrm{mg} \mathrm{P} \mathrm{kg}^{-1}\right)\end{array}$ & $\begin{array}{l}\text { H3A P } \\
\left(\mathrm{mg} \mathrm{P} \mathrm{kg}^{-1}\right)\end{array}$ & M3PSR & $\begin{array}{l}\text { H3A } \\
\text { PSR }\end{array}$ & $\begin{array}{l}\text { WSP } \\
\left(\mathrm{mg} \mathrm{P} \mathrm{kg}^{-1}\right)\end{array}$ & $\begin{array}{l}\text { M3P } \\
\left(\mathrm{mg} \mathrm{P} \mathrm{kg}^{-1}\right)\end{array}$ & $\begin{array}{l}\text { H3A P } \\
\left(\mathrm{mg} \mathrm{P} \mathrm{kg}^{-1}\right)\end{array}$ & WSP & M3P & H3A P \\
\hline Unfertilized & 0.0 & & $2.20 \mathrm{bc}$ & $26.2 b$ & 19.4 & 0.018 & 0.089 & $0.89 \mathrm{c}$ & 20.4 & 12.7 & $2.47 b c$ & 1.58 & 1.56 \\
\hline DAP & 9.6 & Surface & $2.21 b c$ & $26.6 b$ & 19.6 & 0.013 & 0.092 & $1.19 b c$ & 13.8 & 10.5 & $1.88 \mathrm{bc}$ & 2.28 & 1.88 \\
\hline DAP & 24.4 & Surface & $2.06 \mathrm{bc}$ & $30.2 b$ & 21.1 & 0.012 & 0.094 & $1.10 \mathrm{bc}$ & 13.9 & 10.0 & $1.89 \mathrm{bc}$ & 2.32 & 2.19 \\
\hline MAP & 9.6 & Surface & $1.82 \mathrm{c}$ & $31.1 b$ & 21.0 & 0.016 & 0.092 & $1.17 b c$ & 16.7 & 10.9 & $1.62 \mathrm{c}$ & 2.31 & 1.93 \\
\hline MAP & 24.4 & Surface & $3.20 b c$ & $27.3 b$ & 21.1 & 0.012 & 0.091 & $0.97 \mathrm{c}$ & 13.8 & 9.7 & $3.35 b$ & 2.05 & 2.10 \\
\hline Poly & 9.6 & Knifed & $3.88 \mathrm{~b}$ & $40.2 b$ & 26.5 & 0.026 & 0.153 & $1.35 a b$ & 26.7 & 12.0 & $2.89 \mathrm{bc}$ & 1.49 & 2.20 \\
\hline DAP & 24.4 & Disked & $6.02 a$ & $62.0 a$ & 38.9 & 0.014 & 0.123 & $1.09 b c$ & 16.0 & 11.9 & $5.37 a$ & 5.26 & 3.50 \\
\hline DAP & 9.6 & Cover crop & $2.64 b c$ & $38.2 b$ & 23.9 & 0.021 & 0.104 & $1.55 a$ & 21.9 & 14.3 & $1.70 c$ & 1.86 & 1.69 \\
\hline DAP & 24.4 & Cover crop & $1.96 \mathrm{bc}$ & $26.3 b$ & 24.4 & 0.018 & 0.089 & $0.98 \mathrm{c}$ & 19.6 & 12.5 & $2.01 \mathrm{bc}$ & 2.58 & 2.09 \\
\hline \multicolumn{3}{|l|}{ PANOVA } & $<0.010$ & $<0.010$ & 0.099 & 0.186 & 0.244 & $<0.010$ & 0.226 & 0.077 & $<0.001$ & 0.097 & 0.149 \\
\hline \multicolumn{3}{|c|}{$P$ contrast source } & 0.594 & 0.901 & 0.869 & 0.767 & 0.936 & 0.520 & 0.747 & 0.975 & 0.267 & 0.878 & 0.959 \\
\hline \multicolumn{3}{|c|}{$P$ contrast rate } & 0.383 & 0.987 & 0.856 & 0.560 & 0.972 & 0.204 & 0.736 & 0.491 & 0.113 & 0.889 & 0.569 \\
\hline \multicolumn{3}{|c|}{$P$ contrast placement } & $<0.001$ & $<0.001$ & $<0.010$ & 0.091 & $<0.050$ & 0.495 & 0.092 & 0.152 & $<0.001$ & 0.183 & 0.058 \\
\hline \multicolumn{3}{|c|}{$P$ contrast cover crop } & 0.812 & 0.161 & 0.385 & 0.104 & 0.849 & 0.281 & 0.118 & $<0.050$ & 0.954 & 0.693 & 0.729 \\
\hline
\end{tabular}

Notes: WSP = water soluble phosphorus. M3P = Mehlich-3 phosphorus. H3A P = Haney Soil Test phosphorus. M3PSR = Mehlich-3 phosphorus sorption ratio. H3A PSR $=$ Haney Soil Test phosphorus sorption ratio. $\mathrm{DAP}=$ diammonium phosphate. $\mathrm{MAP}=$ monoammonium phosphate. Poly $=$ polyphosphate . Values within a column followed by different letters are significantly different at $p<0.05$.

imized P stratification (Garcia et al. 2007). Further, since soil sampling occurred 24 hours after tillage, the increased $\mathrm{P}$ concentrations at the surface were the result of organic matter mineralization. Release of $\mathrm{CO}_{2}$ is often observed after tillage (Omonode et al. 2007). Concomitant with mineralization of organic matter would be the release of $\mathrm{P}$ to the soil solution. In a study of $\mathrm{P}$ mineralization over a 60 hour period, more carbon (C) was incorporated into microbial biomass than $\mathrm{P}$, resulting in net mineralization of $\mathrm{P}$ (Spohn and Kuzyakov 2013).

Cropping Systems Management and Hydrology. There were no significant differences in the hydrology parameters measured as a part of this study (table 3 ). Time to runoff ranged from 420 to 868 seconds. Mean measured precipitation intensity was $67 \mathrm{~mm} \mathrm{~h}^{-1}$ $\left(2.6 \mathrm{in} \mathrm{hr}^{-1}\right)$. Discharge from plots ranged from 19.3 to $34.5 \mathrm{~L}$ (5.1 to $9.1 \mathrm{gal}$ ), with an average across all treatments of $26.8 \mathrm{~L}(7.1 \mathrm{gal})$. As with the other hydrology variables, there was no significant difference for the discharge to precipitation ratio between treatments.

Fertilizer Source and Runoff Water Quality. MAP and DAP treatments significantly increased nutrient loads and concentrations compared to the unfertilized treatments (table 4). Contrasts indicated no significant trend in SP loads or concentrations when comparing MAP to DAP. There was a trend $(p<0.15)$ for higher TP, $\mathrm{NH}_{4}-$
$\mathrm{N}$, and TKN loads from DAP than MAP. For FWMC, there were no significant differences between fertilizer sources in SP or TP; however, TKN and $\mathrm{NH}_{4}-\mathrm{N}$ FWMC were generally greater from DAP compared to MAP.

Contrasts to compare the low rate of fertilizer application and the high rate suggests decreasing application rates alone would not have any impact on runoff water quality nor on the water quality of receiving waters (table 4). With regard to surface applications, the only significant differences between rates was for MAP when comparing TP and $\mathrm{NH}_{4}-\mathrm{N}$ FWMC. MAP applied at the high rate resulted in TP and $\mathrm{NH}_{4}-\mathrm{N}$ FWMC concentrations (10.4 and $2.3 \mathrm{mg} \mathrm{L}^{-1}$ ) that were twice those of MAP applied at the low rate $\left(5.7\right.$ and $1.2 \mathrm{mg} \mathrm{L}^{-1}$ ).

It is not unexpected that there would be little difference in $\mathrm{P}$ loss between MAP and DAP since they are both $>90 \%$ soluble. One method to reduce $\mathrm{P}$ runoff might be to use less SP sources, such as single super phosphate (SSP). Others researchers have found that the solubility of the $\mathrm{P}$ source had a tremendous impact on SP loss (Hart et al. 2004). When $P$ sources with varying $P$ solubility were applied at $35 \mathrm{~kg} \mathrm{P} \mathrm{ha}{ }^{-1}(31.2$ lb $\left.\mathrm{P} \mathrm{ac}{ }^{-1}\right)$, SP loads were 0.01 to $0.75 \mathrm{~kg}$ $\mathrm{P} \mathrm{ha}^{-1}\left(0.01\right.$ to $\left.0.67 \mathrm{lb} \mathrm{P} \mathrm{ac}{ }^{-1}\right)$ greater than unfertilized plots, predominately due to the solubility of the P fertilizer source (Nguyen et al. 2002). Applying four times as much commercial fertilizer to plots resulted in a 6.7 fold increase in P loss (Rechcigl et al. 1992). No consistent trend was observed with fertilizer rate in this study, potentially because the range in rates was not great enough.

Fertilizer Placement and Runoff Water Quality. Contrast comparison for nutrient loads and FWM concentrations indicated significant differences between treatments and that there may be beneficial, or in some instances detrimental water quality impacts to incorporating $\mathrm{P}$ fertilizers (table 4). Soluble P loads and FWM concentrations were significantly lower from the knifed Poly treatment and the disked DAP treatment compared to the surface applied DAP treatments. Total P was significantly lower (128 mg $0.005 \mathrm{oz}$ ) from knifed Poly compared to surface applied DAP (456 to $555 \mathrm{mg}$ [0.016 to $0.02 \mathrm{oz}]$ ) or DAP that had been disked into the soil $(654 \mathrm{mg}$ [0.023 oz]). While sediment loads were numerically the greatest from the disked DAP treatment, this comparison was not significant at $p<0.05$. However, this treatment did result in significantly greater sediment concentrations than the other treatments. Similarly, the disked DAP treatment resulted in the greatest TKN load and FWMC.

No-till has often been shown to decrease TP and sediment losses compared to tillage (Andraski et al. 1985; McIsaac et al. 1995; 


\section{Table 3}

Hydrologic response to fertilizer source, placement, rate, and cover crop treatments.

\begin{tabular}{lrlllll}
\hline Source & Rate & Placement & $\begin{array}{l}\text { Runoff } \\
\text { time } \mathbf{( s )}\end{array}$ & $\begin{array}{l}\text { Intensity } \\
\left(\mathbf{m m ~ h}^{-\mathbf{1}}\right)\end{array}$ & $\begin{array}{l}\text { Discharge } \\
\mathbf{( L )}\end{array}$ & $\begin{array}{l}\text { Discharge/ } \\
\text { precipitation }\end{array}$ \\
\hline Unfertilized & 0.0 & & 696 & 63.9 & 22.1 & 0.282 \\
DAP & 9.6 & Surface & 420 & 70.5 & 30.1 & 0.372 \\
DAP & 24.4 & Surface & 641 & 72.2 & 34.9 & 0.368 \\
MAP & 9.6 & Surface & 611 & 66.8 & 29.3 & 0.381 \\
MAP & 24.4 & Surface & 868 & 63.9 & 19.3 & 0.219 \\
Poly & 9.6 & Knifed in & 582 & 65.5 & 20.7 & 0.233 \\
DAP & 24.4 & Disked in & 779 & 62.8 & 34.5 & 0.395 \\
DAP + CC & 9.6 & Surface & 641 & 66.8 & 23.4 & 0.267 \\
DAP + CC & 24.4 & Surface & 426 & 72.4 & 26.5 & 0.318 \\
\hline$P$ & & & 0.3552 & 0.8757 & 0.7833 & 0.8899 \\
\hline
\end{tabular}

Notes: $\mathrm{DAP}=$ diammonium phosphate. $\mathrm{MAP}=$ monoammonium phosphate. Poly = polyphosphate . $\mathrm{CC}=$ cover crop.

Smith et al. 2015a). Previous studies also found that no-till generally increased SP losses compared to tillage. Sharpley (2003) observed that after chisel plowing and establishing cover on the bare soil, there was a $90 \%$ decrease in SP and $47 \%$ decrease in TP compared to untilled soil. Tillage decreased $\mathrm{SP}$ without impacting particulate $\mathrm{P}$ compared to no-till from cotton fields in Alabama (Soileau et al. 1994). Incorporating chemical fertilizers has been shown to decrease SP, $\mathrm{TP}$, and $\mathrm{NH}_{4}-\mathrm{N}$ losses compared to surface broadcast applications (Pote et al. 2006).

Liquid fertilizers have been shown to decrease nutrient losses compared to granular fertilizers. In a study where solid SSP or liquid SSP was applied at the same rate, liquid application reduced SP loss by 54\% compared to the dry granular fertilizer (Sharpley and Syers 1983). As a follow-up to the current study, Smith et al. (2016) observed that surface applied Poly could reduce SP by $98 \%$ compared to surface applied MAP or DAP. Further, placing MAP $1 \mathrm{~cm}$ (0.4 in) below the surface resulted in a $98 \%$ decrease in SP loss compared to surface applied MAP.There was a $28 \%$ reduction in SP loads when comparing the subsurface application of Poly to the surface Poly application, but this difference was not significant (Smith et al. 2016). Results from the current study and others may indicate that liquid fertilizers may pose a lower risk of $\mathrm{P}$ loss to surface water than dry fertilizers. Before this recommendation can be fully supported, field studies that monitor surface runoff and tile discharge from fields should be used to confirm that there is no negative impact on drainage water quality. This is especially poignant, since the vast majority of soils in the WLEB are tile drained (Smith et al. 2008, 2015b).

Fertilizers, Cover Crops, and Runoff Water Quality. Soluble P loads from the cover crop treatments were statistically similar to that of the surface DAP applications without cover crops (table 4). This is an important finding for conservation in the WLEB, as many believe that since cover crops work so well at reducing $\mathrm{N}$ loss that they will also result in decreased SP losses. The statistical contrast comparisons for cover crops suggested a trend of lower TP and TKN loads compared to the standard surface applications with no cover crops, but this was not significant.

There was a significant increase in the SP FWMC from the high $\mathrm{P}$ rate cover crop treatment $\left(6.9 \mathrm{mg} \mathrm{L}^{-1}\right)$ compared to the low $\mathrm{P}$ rate cover crop treatment $\left(3.4 \mathrm{mg} \mathrm{L}^{-1}\right.$; table 4). However, neither of the cover crop treatments could be statistically separated by ANOVA or contrast tests from the surface DAP applications without cover crops. Further, there were no significant trends among the cover crop treatments compared to the surface DAP applications without cover crops to result in a significant contrast for any form of runoff $\mathrm{P}$ or sediment. The contrast comparisons indicated a significant increase in $\mathrm{NH}_{4}-\mathrm{N}$ from the cover crop treatments relative to the DAP treatments.

Other studies have shown increased SP loss when cover crops are used, potentially due to senescence or cell lysis in cover crops. Freeze-thaw cycles were shown to increase SP from 0.1 to $10 \mathrm{mg} \mathrm{L}^{-1}$ and TP from 0.5 to $18 \mathrm{mg} \mathrm{L}^{-1}$ (Bechmann et al. 2005). Cover crops are known to concentrate $\mathrm{P}$ in aboveground biomass prior to cell lysis (Ulen
1997). Radish (Raphanus sativus) cover crops have been shown to concentrate surface soil $\mathrm{P}$ within $3 \mathrm{~cm}$ (1.2 in) of the senesced radish plants (White and Weil 2011). Winter cover has been shown to increase SP loads more than 200\% and TP 160\% compared to no winter cover (Liu et al. 2014). While our data were inconclusive on the impact of cover crops on P loss, they are consistent with the literature in that cover crops do not appear to be the solution to decrease P loss to runoff, particularly in areas where soluble $\mathrm{P}$ losses are the primary concern.

Relative Soluble Phosphorus and Total Phosphorus Losses. Data from the 2014 rainfall simulations were used to compare the relative amount of $\mathrm{P}$ lost to the amount of $\mathrm{P}$ that was applied as fertilizer. Figure 1 shows the results of this when regressing the $\mathrm{SP} / \mathrm{P}$ applied to the TP/P applied ratios. When fertilizers were surface applied, a strong correlation occurred between these two variables. Over the rotation in the current study, there was $3,840 \mathrm{mg} \mathrm{P}(0.135 \mathrm{oz})$ applied to plots with the low rate of $\mathrm{P}$ and $4,880 \mathrm{mg}$ P (0.172 oz) applied to plots fertilized at the high rate. The subsurface banded Poly treatment only lost $0.8 \%$ of the $\mathrm{P}$ applied (table 4). The remainder of the treatments lost between $5.6 \%$ and $12 \%$ of the $\mathrm{P}$ applied over the crop rotation during rainfall simulations. Roughly $79 \%$ of the TP lost via runoff from the surface applied treatments was as SP (figure 1), while banding or incorporating fertilizer resulted in roughly $11 \%$ of the TP lost in the soluble form. Based on results from the current study, a follow-up study was conducted to evaluate the role of various $\mathrm{P}$ forms (including MAP and Poly) that were applied at isophosphoric rates (22.7 kg P ha-1 [20.2 $\left.\mathrm{lb} \mathrm{P} \mathrm{ac}^{-1}\right]$ ) either surface broadcast or banded $1 \mathrm{~cm}$ (0.39 in) below the surface (Smith et al. 2016) to runoff boxes measuring $1 \times 0.2 \mathrm{~m}(3.28 \times 0.66 \mathrm{ft})$. Rainfall simulations were conducted at 64 $\mathrm{mm} \mathrm{h}^{-1}\left(2.5 \mathrm{in} \mathrm{hr}^{-1}\right)$. Between $17 \%$ and $19 \%$ of surface applied dry fertilizers were lost as soluble $\mathrm{P}$ in the follow-up study (Smith et al. 2016). In that study, Poly that was surface applied only lost $0.2 \%$ of the applied P. In watersheds such as the WLEB, where increased eutrophication has coincided with increases in SP losses, it is imperative that decision makers manage $\mathrm{P}$ fertilizers for both TP and SP losses. While disking the fertilizer in can reduce the SP, this cannot be done in a no-till context, and the relative TP losses 


\section{Table 4}

Nutrient and sediment loads and concentrations in runoff from fertilization treatments used to study the impact of fertilizer source, placement, rate, and the use of cover crops as potential methods to minimize phosphorus $(P)$ loss from corn-soybean rotation.

\begin{tabular}{|c|c|c|c|c|c|c|c|c|c|c|c|c|}
\hline \multirow[b]{2}{*}{ Source } & \multirow[b]{2}{*}{ Rate } & \multirow[b]{2}{*}{ Placement } & \multicolumn{5}{|l|}{ Load } & \multicolumn{5}{|c|}{ Flow weighted mean concentration } \\
\hline & & & SP (mg) & $\begin{array}{l}\text { TP } \\
\text { (mg) } \\
\end{array}$ & $\begin{array}{l}\mathrm{NH}_{4}-\mathrm{N} \\
(\mathrm{mg})\end{array}$ & $\begin{array}{l}\text { TKN } \\
\text { (mg) } \\
\end{array}$ & $\begin{array}{l}\text { Sediment } \\
\text { (g) }\end{array}$ & $\begin{array}{l}\text { SP } \\
\left(\mathrm{mg} \mathrm{L}^{-1}\right)\end{array}$ & $\begin{array}{l}\mathrm{TP} \\
\left(\mathrm{mg} \mathrm{L}^{-1}\right) \\
\end{array}$ & $\begin{array}{l}\mathrm{NH}_{4}-\mathrm{N} \\
\left(\mathrm{mg} \mathrm{L}^{-1}\right)\end{array}$ & $\begin{array}{l}\text { TKN } \\
\left(\mathrm{mg} \mathrm{L}^{-1}\right)\end{array}$ & $\begin{array}{l}\text { Sediment } \\
\left(\mathrm{g} \mathrm{L}^{-1}\right)\end{array}$ \\
\hline Unfertilized & 0.0 & & $4.07 d$ & $95.7 b$ & $6.9 d$ & $252 c d$ & 192 & $0.079 f$ & $2.18 c$ & $0.14 \mathrm{~g}$ & $5.40 \mathrm{~cd}$ & $4.31 b$ \\
\hline DAP & 9.6 & Surface & $328 a$ & $555 a$ & $171 a$ & $649 b$ & 202 & 4.68ab & 7.89ab & $2.44 b$ & $9.39 b c$ & $3.19 b$ \\
\hline DAP & 24.4 & Surface & $238 a$ & $456 a$ & $112 \mathrm{abc}$ & $494 b c$ & 155 & 3.83abc & $7.37 a b$ & $1.81 \mathrm{bcd}$ & $7.89 \mathrm{bcd}$ & $2.58 b$ \\
\hline MAP & 9.6 & Surface & $201 a b$ & $312 a$ & $62.2 \mathrm{bc}$ & $281 \mathrm{bcd}$ & 79.9 & $3.71 b c$ & $5.70 b$ & 1.15def & $5.18 d$ & $1.54 b$ \\
\hline MAP & 24.4 & Surface & $231 a b$ & $476 a$ & $103 a b c$ & $357 \mathrm{bcd}$ & 189 & $5.20 a b$ & $10.4 a$ & $2.28 \mathrm{bc}$ & $7.86 \mathrm{bcd}$ & $4.28 b$ \\
\hline Poly & 9.6 & Knifed & $18.2 \mathrm{c}$ & $128 b$ & $17.0 d$ & $210 d$ & 75.9 & $0.523 e f$ & $3.16 \mathrm{c}$ & $0.495 f g$ & $5.23 c d$ & $1.87 \mathrm{~b}$ \\
\hline DAP & 24.4 & Disked & $76.3 b$ & $654 a$ & $51.7 \mathrm{c}$ & $1,740 a$ & 756 & $1.02 \mathrm{de}$ & $8.46 a b$ & $0.679 \mathrm{efg}$ & $22.2 a$ & $9.76 a$ \\
\hline DAP & 9.6 & Cover crop & $153 a b$ & $340 a$ & 87.0abc & $275 \mathrm{bcd}$ & 103 & $3.39 \mathrm{bc}$ & 7.18ab & $1.93 \mathrm{bcd}$ & $5.78 \mathrm{~cd}$ & $2.15 b$ \\
\hline DAP & 24.4 & Cover crop & $313 a$ & $425 a$ & $259 a$ & $466 \mathrm{bcd}$ & 98.9 & $6.89 a$ & $9.27 a$ & $5.73 a$ & $10.2 b$ & $2.22 b$ \\
\hline \multicolumn{3}{|l|}{ PANOVA } & $<0.001$ & $<0.01$ & $<0.001$ & $<0.01$ & 0.107 & $<0.001$ & $<0.001$ & $<0.001$ & $<0.01$ & $<0.05$ \\
\hline \multicolumn{3}{|c|}{$P$ contrast source } & 0.199 & 0.115 & 0.060 & 0.055 & 0.338 & 0.801 & 0.735 & 0.078 & 0.043 & 0.730 \\
\hline \multicolumn{3}{|c|}{$P$ contrast rate } & 0.440 & 0.511 & 0.947 & 0.902 & 0.441 & 0.775 & 0.188 & 0.353 & 0.471 & 0.228 \\
\hline \multicolumn{3}{|c|}{$P$ contrast placement } & $<0.001$ & 0.080 & 0.003 & 0.052 & 0.239 & $<0.001$ & 0.027 & $<0.001$ & 0.081 & 0.098 \\
\hline \multicolumn{3}{|c|}{$P$ contrast cover crop } & 0.413 & 0.147 & 0.385 & 0.144 & 0.233 & 0.840 & 0.705 & 0.044 & 0.733 & 0.704 \\
\hline
\end{tabular}

Notes: $\mathrm{SP}=$ soluble phosphorus. $\mathrm{TP}=$ total phosphorus. $\mathrm{NH}_{4}-\mathrm{N}=$ ammonium. $\mathrm{TKN}=$ total Kjehldahl nitrogen. $\mathrm{DAP}=$ diammonium phosphate. $\mathrm{MAP}=$ monoammonium phosphate. Poly = polyphosphate. Values within a column followed by different letters are significantly different at $p<0.05$.

were greater from this treatment than the knifed-in Poly treatment. Knifing Poly in at planting may be the most effective method to provide the emerging crop with $\mathrm{P}$ while minimizing both TP and SP losses. Further study should focus on whether banding dry fertilizers (i.e., MAP or DAP) can effectively decrease P loads. While tile drainage was not a component of this study, we implore future researchers to study systems where tile drainage is monitored. Previous research in the WLEB has shown that as much as $50 \%$ of the P lost from fields occurs via tile drains. While these studies suggested that this was predominately occurring via a surface connection, it may be premature to conclude that knifing Poly in to decrease surface loads would necessarily decrease all P losses from fields in the WLEB.

\section{Summary and Conclusions}

We examined four potential strategies to minimize P loss from a corn-soybean rotation: (1) applying fertilizers annually versus once during the rotation, (2) using alternate $\mathrm{P}$ sources commercially available in the region, (3) incorporating versus surface applying fertilizers, and (4) using cover crops to retain $\mathrm{P}$. This is the first study to evaluate all of the practices simultaneously, which is critical to conservation management in the WLEB, as these are some of the primary practices that have been identified

\section{Figure 1}

Soluble phosphorus $(\mathrm{P})$ lost relative to the amount of $\mathrm{P}$ applied as a function of the fraction of the total $P$ lost relative to the amount of $P$ applied during the 2014 rainfall simulation studies. The solid line represents treatments with surface applied $P$ fertilizer while the dashed line represents treatments where the fertilizer was incorporated.

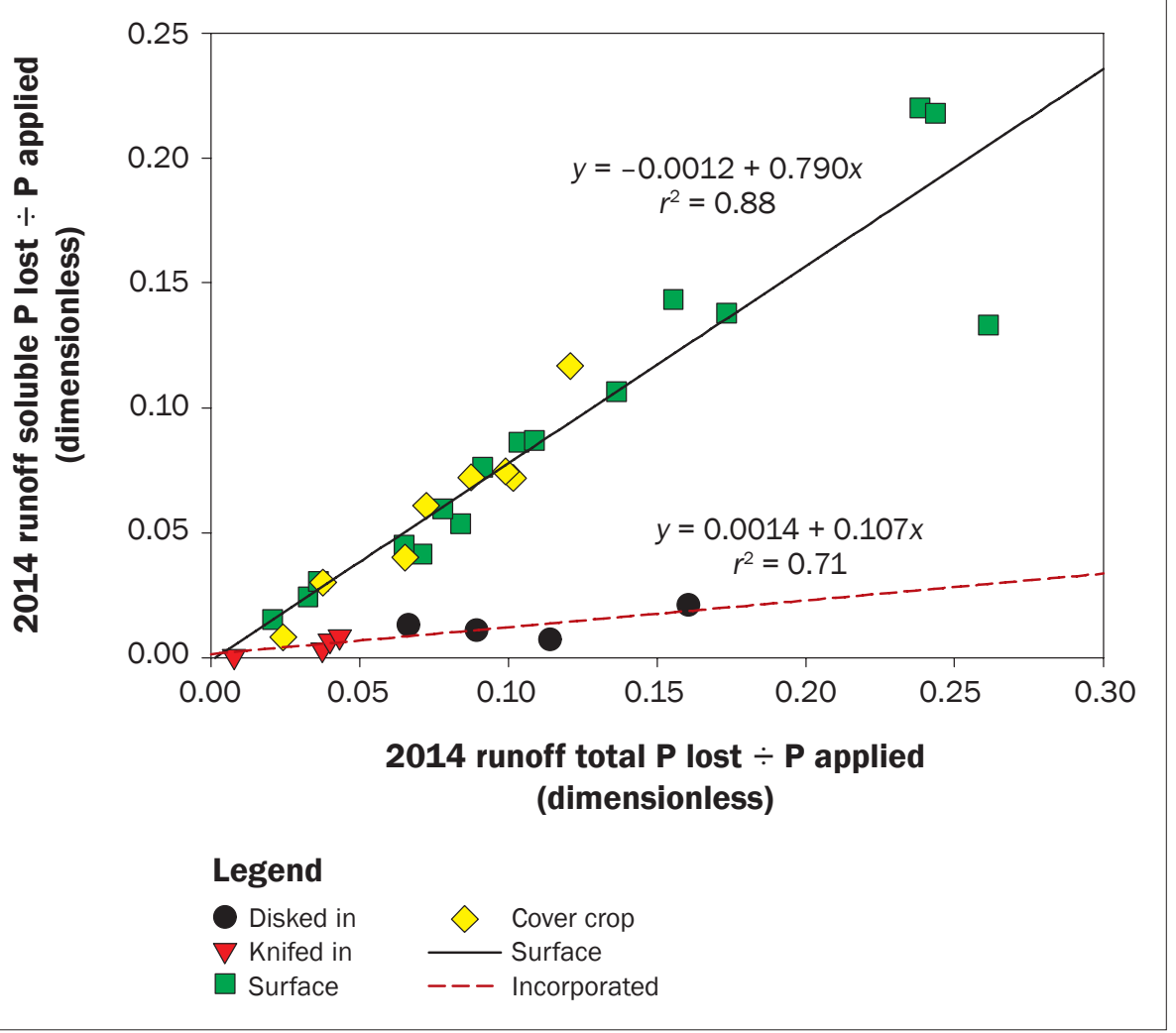


as the potential solutions for $\mathrm{P}$ stratification and $\mathrm{P}$ runoff. Three years into this study, none of the fertilization strategies appreciably diminished P stratification. While rainfall simulation data are easily misinterpreted by over-simplifying the results and upscaling them to field or watershed scale estimates, they can provide valuable side-by-side comparisons of the acute nutrient losses from treatments. Cover crops did not decrease SP loading in this study. While cover crops are likely to solve some resource concerns, results from this study combined with others are inconclusive as to whether or not cover crops will be an appropriate solution where soluble $\mathrm{P}$ is a primary resource concern. Of the practices investigated, incorporation of fertilizer or subsurface injection of liquid $\mathrm{P}$ fertilizer are the practices that had the lowest SP loss. Incorporation of $\mathrm{P}$ fertilizers with tillage will likely result in greater erosion and TP losses, which must be taken into account with the relevant resource concerns by land managers and policy makers. We encourage the fertilizer industry to give strong consideration to use of alternative $\mathrm{P}$ fertilizers that will reduce SP losses in sensitive watersheds, such as the WLEB. Further, before firm recommendations can be made, other researchers are encouraged to perform field-scale experiments on the use of liquid fertilizers or less soluble fertilizers to ensure they do not decrease surface runoff SP loading while increasing SP discharge through subsurface tile. With water quality in Lake Erie now recognized as a public health issue, it is vital that more studies such as this be conducted to examine specific practices or combinations of practices to limit P losses from the landscape.

\section{Acknowledgements}

The authors wish to acknowledge the efforts of Katelin Fisher, Janae Bos, and the many student workers at the National Soil Erosion Research Laboratory (West Lafayette, Indiana) for their efforts during rainfall simulations. Also, we appreciate the Throckmorton Purdue Agricultural Center (TPAC) staff in Lafayette, Indiana, for their cooperation on this project. Mention of trade name does not imply endorsement by USDA to the exclusion of other suitable alternatives.

\section{References}

Andraski, B.J., D.H. Mueller, and T.C. Daniel. 1985 Phosphorus losses in runoff as affected by tillage. Soil Science Society of America Journal 49(6):1523-1527.
Baker, D.B., and R.P. Richards. 2002. Phosphorus budgets and riverine phosphorus export in northwest Ohio. Journal of Environmental Quality 31:96-108.

Bechmann, M.E., P.J.A. Kleinman, A.N. Sharpley, and L.S Saporito. 2005. Freeze-thaw effects on phosphorus loss in runoff from manured and catch-cropped soils. Journal of Environmental Quality 34(6):2301-2309.

Cade-Menun, B.J., Z. He, H. Zhang, D.M. Endale, H.H. Schomberg, and C.W. Liu. 2015. Stratification of phosphorus forms from long-term conservation tillage and poultry litter application. Soil Science Society of America Journal 79(2):504-516.

Chaffin, J.D., T.B. Bridgeman, S.A. Hechathorn, and S Mishra. 2011. Assessment of Microcystis growth rate potential and nutrient status across a trophic gradient on western Lake Erie. Journal of Great Lakes Research 37:92-100.

Costa, S.E.V.G.A., E.D. Souza, I. Anghnoni, J.P.C. Flores, F.C.B. Viera, A.P. Martins, and E.V.O. Ferreira. 2010 Patterns in phosphorus and corn root distribution and yield in long-term tillage systems with fertilizer applications. Soil and Tillage Research 109:41-49.

Cruse, R.M., G.A. Yakle, T.C. Colvin, D.R. Timmons, and A.L. Mussleman. 1983. Tillage effects on corn and soybean production in farmer-managed, universitymonitored field plots. Journal of Soil and Water Conservation 38(6):512-514.

Frankenberger, J., D. Smith, P. Kleinman, K. King, L. Norfleet, and S. McKinney. 2012. Conservation recommendations for decreasing phosphorus loading to western Lake Erie Basin and Grand Lake St. Marys. Washington, DC: USDA Natural Resource Conservation Service.

Garcia, J.P., C.S. Wormann, M. Mamo, D. Drijber, and D. Tarkalson. 2007. One-time tillage of no-till: Effects on nutrients, mycorrhizae, and phosphorus uptake. Agronomy Journal 99:1093-1103.

Gaynor, J.D., and W.I. Findlay. 1995. Soil and phosphorus loss from conservation and conventional tillage in corn production. Journal of Environmental Quality 24:734-741.

Haney, R.L., E.B. Haney, L.R. Hossner, and J.G. Arnold. 2010. Modifications to the new soil extractant H3A1: A multinutrient extractant. Communications in Soil Science and Plant Analysis 41:1513-1523.

Hart, M.R., B.F. Quin, and M.L. Nguyen. 2004. Phosphorus runoff from agricultural land and direct fertilizer effects: A review. Journal of Environmental Quality 33(6):1954-1972.

Howard, D.D., M.E. Essington, and D.D. Tyler. 1999 Vertical phosphorus and potassium stratification in no-till cotton soils. Agronomy Journal 91(2):266-269.

Houx, III, J.H., W.J. Wiebold, and F.B. Fritschi. 2011. Long-term tillage and crop rotation determines the mineral nutrient distributions of some elements in a Vertic Epiaqualf. Soil and Tillage Research 112:27-35.
Joose, P.J., and D.B. Baker. 2011. Context for re-evaluating agricultural source phosphorus loadings to the Great Lakes. Canadian Journal of Soil Science 91:317-327.

Liu, K., J.A. Elliott, D.A. Lobb, D.N. Flaten, and J. Yarotski. 2014. Nutrient and sediment losses in snowmelt runoff from perennial forage and annual cropland in the Canadian prairies. Journal of Environmental Quality 43(5):1644-1655.

Maguire, R.O., and J.T. Sims. 2002. Soil testing to predict phosphorus leaching. Journal of Environmental Quality 31(5):1601-1609

Mamo, M., D. Ginting, C.W. Zanner, D.L. McCallister, R.R. Renken, and C.A. Shapiro. 2005. Phosphorus stratification and potential for runoff loss following long term manure application. Journal of Soil and Water Conservation 60(5):243-250.

Maxwell, S. 2014. USDA invests new conservation finds to improve Lake Erie water quality. http://www.usda. gov/wps/portal/usda/usdahome? contentid $=2014 / 08 /$ 0180.xml.

McIsaac, G.F., J.K. Mitchell, and M.C. Hirschi. 1995 Dissolved phosphorus concentrations in runoff from simulated rainfall on corn and soybean tillage systems. Journal of Soil and Water Conservation 50(4):383-387.

Mehlich, A. 1984. Mehlich 3 soil test extractant: A modification of Mehlich 2 extractant. Communications in Soil Science and Plant Analysis 15:1409-1416.

Nguyen, M.L., B.F. Quin, and J.P.S. Sukias. 2002. Potential losses of phosphorus and nitrogen in runoff and drainage from pastoral soils applied with superphosphate and reactive phosphate rock. In Dairy Farm Soil Management. Occasional Report 15, eds. L.D. Currie and P. Logan than, 137-153. Palmerston North, New Zealand: Massey University.

Omonode, R.A., A. Gal, D.R. Smith, and T.J. Vim. 2007. Soil carbon dioxide and methane fluxes from long-term tillage systems in continuous corn and corn-soybean rotations. Soil and Tillage Research 95:19-26.

Pote, D.H., W.L. Gingery, G.E. Aiken, F.X. Han, and P.A. Moore, Jr. 2006. Incorporating granular inorganic fertilizer into perennial grassland soils to improve water quality. Journal of Soil and Water Conservation 61(1):1-7.

Rechcigl, J.E., G.G. Payne, A.B. Botcher, and P.S. Porter 1992. Reduced phosphorus application on Bahia grass and water quality. Agronomy Journal 84(3):463-468.

Richards, R.P., and D.B. Baker. 1993. Trends in nutrient and sediment concentrations in Lake Erie tributaries, 1975-1990. Journal of Great Lakes Research 19:200-211.

Richards, R.P., D.B. Baker, and D.J. Eckert. 2002. Trends in agriculture in the LEASEQ watersheds, 1975-1995. Journal of Environmental Quality 31:17-24.

Robbins, S.G., and R.D. Voss. 1991. Phosphorus and potassium stratification in conservation tillage systems. Journal of Soil and Water Conservation 46(4):298-300. 
Scheiner, J.D., and R.S. Lavado. 1998. The role of fertilization on phosphorus stratification in no-till soils. Communications in Soil Science and Plant Analysis 29(17\&18):2705-2711.

Schwab, G.J., D.A.Whitney, G.L. Kilgore, and D.W. Sweeney. 2006. Tillage and phosphorus management effects on crop production in soils with phosphorus stratification. Agronomy Journal 98(3):430-435.

Self-Davis, M.L., and P.A. Moore, Jr. 2000. Determining water-soluble phosphorus in animal manure. In Methods of Phosphorus Analysis for Soils, Sediments, Residuals, and Waters, ed. G.M. Pierzynski, 74-76. Southern Cooperative Series Bulletin \#396. Raleigh, NC: North Carolina State University.

SERA-17. 2015. National Research Project for Simulated Rainfall - Surface Runoff Studies. https://sera17dotorg. files.wordpress.com/2015/02/national-p-protocol.pdf.

Sharpley, A.N. 2003. Soil mixing to decrease surface stratification of phosphorus in manured soils. Journal of Environmental Quality 32(4):1375-1384.

Sharpley, A., B. Foy, and P. Withers. 2000. Practical and innovative measures for the control of agricultural phosphorus losses to water: An overview. Journal of Environmental Quality 29(1):1-9.

Sharpley, A., P. Richards, S. Herron, and D. Baker. 2012. Case study comparison between litigated and voluntary nutrient management strategies. Journal of Soil and Water Conservation 67(5):442-450, doi:10.2489/ jswc.67.5.442.

Sharpley, A.N., S.J. Smith, J.R. Williams, O.R. Jones, and G.A. Coleman. 1991. Water quality impacts associated with sorghum culture in the southern plains. Journal of Environmental Quality 20(1):239-244.

Sharpley, A.N., and J.K. Syers. 1983. Transport of phosphorus in surface runoff as influenced by liquid and solid fertilizer phosphate addition. Water, Air, and Soil Pollution 19:321-326.

Soileau, J.M., J.T. Touchton, B.F. Hajek, and K.H. Yoo. 1994. Sediment, nitrogen and phosphorus runoff with conventional- and conservation-tillage cotton in a small watershed. Journal of Soil and Water Conservation 49(1):82-89.

Smith, D.R., W. Francesconi, S.J. Livingston, and C. Huang. 2015a. Phosphorus losses from monitored fields with conservation practices in the Lake Erie Basin, USA. Ambio 44(suppl. 2):S319-S331.

Smith, D.R., R.D. Harmel, M. Williams, R. Haney, and K.W. King. 2016. Managing acute phosphorus loss with fertilizer source and placement: Proof of Concept. Agricultural and Environmental Letters1:150015, doi:10.2134/ael2015.01.0001.

Smith, D.R., J.W. King, L. Johnson, W. Francesconi, P. Richards, D. Baker, and A.N. Sharpley. 2015b. Surface runoff and tile drainage transport of phosphorus in the Midwestern United States. Journal of Environmental Quality 44:495-502.
Smith, D.R., K.W. King, and M.R. Williams. 2015c. What is causing the harmful algal blooms in Lake Erie? Journal of Soil and Water Conservation 70(2):27A-29A, doi:10.2489/jswc.70.2.27A.

Smith, D.R., S.J. Livingston, B.W. Zuercher, M. Larose, G.C. Heathman, and C. Huang. 2008. Nutrient losses from row crop agriculture in Indiana. Journal of Soil and Water Conservation 63(6):396-409, doi:10.2489/ jswc.63.6.396.

Smith, S.J., A.N. Sharpley, J.W. Naney, W.A. Berg, and O.R. Jones. 1991. Water quality impacts associated with wheat culture in the southern plains. Journal of Environmental Quality 20(1):244-249.

Smith, D.R., and E.A. Warnemuende-Pappas. 2015. Vertical tillage impacts on water quality derived from rainfall simulations. Soil and Tillage Research 153(November):155-160, http://dx.doi.org/10.1016/j. still.2015.04.004.

Spohn, M., and Y. Kuzyakov. 2013. Phosphorus mineralization can be driven by microbial need for carbon. Soil Biology and Biochemistry 61:69-75.

Ulen, B. 1997. Nutrient losses by surface run-off from soils with winter cover crops and spring-ploughed soils in the south of Sweden. Soil and Tillage Research 44:165-177.

USEPA (US Environmental Protection Agency). 1983. Methods for chemical analysis of water and wastes. USEPA-600/4-79-020. Cincinnati, OH: US Environmental Protection Agency.

Vitosh, M.L., J.W. Johnson, and D.B. Mengel. 1995. TriState Fertilizer Recommendations for Corn, Soybeans, Wheat and Alfalfa. https://www.extension.purdue. edu/extmedia/AY/AY-9-32.pdf.

White, C.M., and R.R. Weil. 2011. Forage radish cover crops increase soil test phosphorus surrounding radish taproot holes. Soil Science Society of America Journal 74(1):121-130.

Zhao, S.L., S.C. Gupta, D.R. Huggins, and J.F. Moncrief. 2001. Tillage and nutrient source effects on surface and subsurface water quality at corn planting. Journal of Environmental Quality 30:998-1008. 